\title{
AUSTRIAN AND UKRAINIAN COMPARATIVE STUDY OF E-JUSTICE: TOWARDS CONFIDENCE OF JUDICIAL RIGHTS PROTECTION
}

\author{
Henriette Christine Boscheinen-Duursma \\ Em. Rechtsanwalt Priv.-Doz. Mag. Dr., LL.M., M.A.S., \\ LL.M. Salzburg University, Austria \\ Roksolana Khanyk-Pospolitak, \\ PhD in Law, Chair of Private Law Department, \\ Faculty of Law, National University Kyiv-Mohyla Academy, \\ Ukraine
}

doi.org/10.33327/AJEE-18-2.4-a000022

\begin{abstract}
Summary: 1. Introduction. - 2. E-justice in Ukraine and in Austria. - 2.1. E-justice and the Tasks of the Civil Procedure. - 2.2. Current State and Strategy of E-justice Development in Ukraine. - 2.3. Current State and Strategy of E-justice Development in Austria. - 2.4. Common Elements of E-justice in Ukraine and Austria. - 2.4.1. Submission of the Statement of Claim, Applications, other Documents to the Court in Electronic Form. -2.4.2. Electronic Evidence. - 2.4.3. Consideration of the Case in Electronic Form. - 3. Potential Risks and Benefits of E-justice Experience in Austria and Ukraine. - 3.1. The Main Features of E-justice and Risks. - 3.2. What Makes the Procedure More Effective? - 4. Conclusions.
\end{abstract}

The article is devoted to the comparative analysis of e-justice in Ukraine and Austria, in particular, the authors describe the current situation, strategy of e-justice development in Ukraine and Austria, as well as the potential risks, problems and benefits of introducing e-justice in Ukraine.

The link between the goals and task of civil proceeding with e-justice was succinctly shown in this article. Also, the common elements of e-justice in Ukraine and Austria were highlighted, among them the following three elements were analysed in depth: an appeal to court with different documents, electronic evidence and consideration of the case in electronic form.

Based on the comparative analysis, conclusions about what is common and different in e-justice in Ukraine and Austria and the value Ukraine should take from the experience of e-justice in Austria were drawn. 
Keywords: e-justice, Single Judicial System, elements of e-justice, electronic legal communication, Austrian e-justice system.

\section{INTRODUCTION}

Ukraine is a member of the Council of Europe, and therefore the right to judicial protection is reflected in Art. 55 of the Constitution of Ukraine, ${ }^{1}$ as well as in the procedural codes, in particular the Civil Procedural Code of Ukraine, the Commercial Procedural Code of Ukraine and the Code of Administrative Proceedings of Ukraine.

In 2014, Ukraine signed an Association Agreement with the European Union, where Art. 14 Section III stipulates that 'Within the framework of cooperation in the field of justice, freedom and security, the Parties attach particular importance to the establishment of the rule of law and the strengthening of institutions of all levels in the field of general administration and law enforcement and judicial authorities in particular. Cooperation will be aimed, in particular, at strengthening the judiciary, improving its effectiveness, ensuring its independence and impartiality and fighting corruption. Cooperation in the field of justice, freedom and security will take place on the basis of respect for human rights and fundamental freedoms.'

Since 2016 Ukraine has been undergoing judicial reforms. Corresponding changes were made to the Constitution of Ukraine in the area of justice and a new version of the Law of Ukraine 'On the Judiciary and Status of Judges' was adopted, according to which the court system is changed and new approaches are introduced in the selection and appointment of judges.

In the further amendments to the Constitution of October 2017, the new editions of the three procedural codes of Ukraine - Civil Procedural, Commercial Procedural and the Code of Administrative Proceedings - were adopted. The new codes, despite their shortcomings, look at the best European approaches to justice. The results of the reform have been modest so far, but hopefully the situation will improve, even though slowly. ${ }^{3}$

One of the tasks of the judicial reform was the introduction of effective mechanisms for the protection of the rights and interests of individuals and legal entities and the simplification of the accessibility of justice. Among the mechanisms aimed at facilitating access to justice is the introduction of e-justice, which has long been successfully functioning and applied in other EU countries, and in particular in Austria, where e-justice is highly developed. Therefore, with the introduction of e-justice in Ukraine, the experience of Austria (both positive and negative) is of considerable interest.

1 TheConstitution ofUkraine<http://zakon2.rada.gov.ua/laws/show/254\%D0\%BA/96-\%D0\%B2\%D1\%80> accessed 9 December 2019.

2 EU-Ukraine Association Agreement <http://ukraine-eu.mfa.gov.ua/en/page/open/id/2900> accessed 9 December 2019.

3 See Elisabetta Silvestri, 'Notes on Case Management in Italy' (IALP 2017 China Conference On Judicial Management from comparative perspective',Tianjin, 8-10 Nov. 2017), Session 2 on 'Case Management', General Reporter - Dr. John Sorabji. 


\section{E-JUSTICE IN UKRAINE AND IN AUSTRIA}

\subsection{E-justice and the Tasks of the Civil Procedure}

It would be easy to state the obvious and repeat that in all justice systems of the world the role of civil justice is to apply the applicable substantive law to the established facts in an impartial manner, and pronounce fair and accurate judgments. ${ }^{4}$

The main tasks of the civil process are fair, impartial and timely consideration and resolution of civil cases in order to protect the violated, unrecognized or disputed rights, freedoms or interests of individuals, the rights and interests of legal entities, and the interests of the state. Different institutes, tools and mechanisms are used to achieve the purpose of legal proceedings and the accomplishment of tasks. One of these can be called e-justice. E-justice is a mechanism that enhances transparency, effectiveness and access to justice. Use of appropriate communication technology - especially when parties cannot physically be present in court - is considered to be one of the common minimum standards of civil procedure. ${ }^{5}$

\subsection{Current State and S-trategy of E-justice Development in Ukraine}

In all three new procedural codes - the Civil Procedural, Commercial Procedural and the Code of Administrative Proceedings, adopted by the Parliament of Ukraine on 3 October 2017, the introduction of the Single Judicial Information and Telecommunication System (hereinafter, the Judicial System) ${ }^{6}$ is envisaged. The consolidation of the law on the Judicial System is evidence of the penetration of the latest information technologies into the field of justice and the subsequent consistent implementation of e-justice in Ukraine. This fully corresponds to the tasks set out in the Strategy for the reform of the judiciary, justice and related legal institutes for 2015-2020.?

It is worth pointing out that the introduction of the Judicial System is not something completely new to Ukrainian legal proceedings. The procedural codes that had been in force before already contained a norm on the Automated System of the Documentation of the Court (Article 11-1 of the CPCU, Article 2-1 of the CPCU, Article 15-1 of the $\mathrm{CAPU}){ }^{8}$ If one compares the rules of the existing procedural codes with the previous

$4 \quad$ See Alan Uzelac (ed), Goals of Civil Justice and Civil Procedure in Contemporary Judicial Systems (Springer 2014) 3.

5 European Parliament Resolution of 4 July 2017 with recommendations to the Commission on common minimum standards of civil procedure in the European Union (2015/2084(INL)).

6 In addition to the Judicial System in Ukraine there are number of other registries that are in some way related to the judicial system: the Register of Enforcement Proceedings, the Single Register of Debtors, the Register of Advocates of Ukraine, Unified State Register of Legal Entities, Individual Entrepreneurs and Public Associations and others.

7 See Strategy for the reform of the judiciary, justice and related legal institutes for 2015-2020 <http:// zakon2.rada.gov.ua/laws/show/276/2015> accessed 9 December 2019.

8 See Civil Procedure Code of Ukraine <http://zakon3.rada.gov.ua/laws/show/1618-15/ed20170803> accessed 9 December 20191; Commercial Procedural Code of Ukraine <http://zakon2.rada.gov.ua/ laws/show/1798-12/ed20170803> accessed 9 December 2019; Code of Administrative Proceedings of Ukraine <http://zakon2.rada.gov.ua/laws/show/2747-15/ed20170803> accessed 9 December 2019. 
codes, one can notice immediately not only the textual differences, but also the differences in the content.

The Judicial System contains elements of e-justice already in operation, such as the registration of documents submitted to courts; the distribution of cases between judges, that is the determination of a judge or board of judges for the consideration of a particular case. There are also new elements, in particular the submission of documents in electronic form; the dispatching of subpoenas not only in paper form; electronic evidence, and so on. There is one example where, in the judicial system, e-justice was incorporated as an experiment in some courts of Ukraine. In particular, the experimental elements used were the exchange of documents between the court and participants in the process.

The new Judicial System is broader in terms of content and range of its users. The automated system of document circulation concerned only the circulation of documents within a particular court and only judges and court personnel could have access to it. Through the Judicial System, a broader circle of individuals - not only court employees, but also other participants (parties, representatives, and the like) - is participating in this process. The Judicial System should become a kind of information platform for the whole array of documents circulating in the courts.

Such an expansion testifies the developments in the implementation of IT technologies in the field of legal proceedings in Ukraine, in particular the availability of experience in its administration and use by potential consumers such as, any judge or other subjects of procedural legal relations.

The idea is to create, in Ukraine, an electronic court, meaning a single platform mirroring the European Union space called E-justice. The introduction of e-justice will facilitate the establishment of mutually beneficial cooperation between Ukraine and the EU, and will be an important step towards a modern legal system. ${ }^{9}$

Currently, ${ }^{10}$ there are no documents on the Strategy for the development of electronic justice in Ukraine. The main task is to draft a Regulation on a Single Judicial Information and Telecommunication System to fully execute the rules of procedural codes. The only way to enable said system to work in Ukraine's Judicial System is to develop and fully enforce the Regulation. Until that moment, the previous system continues to operate.

\subsection{Development, Current State and Strategy of E-Justice in Austria}

Austria has a leading role in the field of e-justice in Europe and the experience of e-justice development is very important and useful for other countries. ${ }^{11}$ Actually,

$9 \quad$ See Iryna Izarova, 'Rozvytok electronnoho pravosyddia v tsuvilnykh spravah u ievropeiskyh krainah' ('Development of e-justice in civil cases in the European countries') (2014) 6 Yurydychnyi Visnyk218.

10 As of August 2018.

11 See Henriette Christine Duursma-Kepplinger, 'Deiaki aspekty avstriiskoho tsyvilnoho prozesualnoho prava yak imovorna model dlia novoho ukrainskoho tsyvilnoho protsesualnoho zakonodavstva' ('Some Aspects of Austrian Civil Procedure Law as a Possible Model for New Ukrainian Civil Procedure Legislation') (2017) 8 Pravo Ukrainy 158. 
Austria was the first country worldwide that established the electronic legal communication. ${ }^{12}$

Information and communications technology is used in the Austrian Justice System in particular in the following areas: ${ }^{13}$ case automation in the justice system ('Verfahrensautomation Justiz'); electronic legal communications; Land Register ('Grundbuch'); Business Register ('Firmenbuch'); documents submission service; database of official publications ('Ediktsdatei') (publications of the Business Register, real property auctions, insolvency database, etc.); Electronic Documents Archive; electronic signature; advances on maintenance; Federal Law Information System (RIS); Justiz Intranet; IT application for the European Payment Order; European Business Register (EBR); video conferencing; form sheets / online submissions.

Before turning to the most important individual applications, the temporal evolution of the e-justice in Austria should be described ${ }^{14}$ (See Table 1)

Table 1. The evolution of the e-justice in Austria

Date Historical Events

1976 The advances on maintenance process resulted in the first IT application in the justice department.

1980 In land database was set up at the Federal Computing Centre and the Austrian justice system started to build a comprehensive IT network.

1986 The 'external searches' of the migrated Land Registers were possible.

1990 The electronic legal communication with the courts was introduced and gradually expanded until 2019.

1991 The change from commercial register law to the Business Register Statute [Firmenbuchgesetz] laid the foundation for the central electronic Business Register.

1997 The Austrian justice system tested voice recognition systems.

1999 The Austrian Land Register could be inspected via the internet from all over the world. Also the European Business Register (EBR) enabled access to the official commercial or business register data of (currently) France, Italy, Germany, the United Kingdom, Belgium, Luxembourg, Spain, Ireland, Latvia, Lithuania, Estonia, Finland, Sweden, Denmark, Norway, Greece, the Netherlands, Malta Jersey, Guernsey, Ukraine, Slovenia, Serbia, Macedonia and Austria via the relevant national provider (in Austria: MANZ'sche Verlags- und Universitätsbuchhandlung $\mathrm{GmbH}$ ) as part of the European Economic Interest Grouping (EEIG). In total more than 20 million business entities can be retrieved online via the EBR.

12 See more Federal Ministry of Justice, e-Justice Austria, IT applications in the Austrian justice system, Information (Revised in December 2017), brochure, p. 4 <https://www.justiz.gv.at/web2013/home/e-ju stice 8ab4ac8322985dd501229ce3fb1900b4.de.html> accessed 9 December.

13 Ibid, 3.

14 Source Federal Ministry of Justice, e-Justice Austria, IT applications in the Austrian justice system, Information (Revised in December 2017), brochure, p. $4<$ https://www.justiz.gv.at/web2013/home/e-ju stice 8ab4ac8322985dd501229ce3fb1900b4.de.html> accessed 9 December 2019. 

year the insolvency database was opened. Insolvencies (bankruptcies, compositions, debt regulations) have been exclusively published on the internet and are legally binding as such.

2001 The electronic submission of annual financial statements to the Business Register was introduced.

2002 The database for real property auctions was set up.

2003 The Database of Official Publications was expanded by inclusion of auction edicts regarding movable items and by the option to search for property owners in criminal cases.

2004 The list of expert witnesses, interpreters, mediators, insolvency administrators and official receivers, and the Lobbying and Interest Group was established.

2005 All publications prescribed for legal proceedings started to be made exclusively in the Database of Official Publications.

2005 All applications and documents received by the Business Register Courts started to be recorded and stored electronically.

2005- The electronic signature of the justice system, by which the court decisions

2006

2005 that would be sent and signed via ELC was introduced.

2017

2006 The New Land Register - the Electronic Collection of Documents was set up. By now more than $90 \%$ of the documents are submitted electronically. All documents have been available for inspection on the Internet via the clearing offices.

2006 The Electronic Documents Archive was set into force.

2007 The Mail Processing Service was put into operation for the first time.

2009 All orders and decisions issued by the Business Register Courts were stored electronically. All relevant documents are available electronically, which allows a completely digital file management in Business Register proceedings.

2009 Electronic search option for the youth welfare offices was implemented and the website of the justice system was completely revised.

2010 Every office belonging to the justice system was connected to the Federal Computing Center at least by an $8 \mathrm{MBit}$ line (CNAx). Also the Electronic Certification Register was established in 2010.

2012 Following other milestones, such as connecting the Land Register to Electronic Legal Communication, processing of court fees in the Land Register and automated issuing of decisions, a technically updated version of the application including new features was made available as of 7 May 2012; since mid-2013 partitioning plans have been registered in the Land Register automatically in cross-departmental cooperation with the surveying offices.

2012 The intranet website, which had initially been designed in a uniform style for the entire department, was completely revised and newly designed and since then has presented itself in a new look in terms of technical, organisational, structural and visual aspects. Localisation was introduced, which means that every court, office and prison has its own virtual intranet site. 
2013 The website of the justice was regularly enhanced and expanded. Every court, every public prosecutors' office and penal institution had its own area and, thus, virtually its own internet presence.

2014- The Family and Youth Court Support Register was established. The form 2015 sheet service was extensively revised; submissions could be transmitted to the courts and public prosecutors' offices via secured electronic communication ('ELC for Everyone'); MOVE (Mein Office Vorlagen Editor (MOVE) [My Office Template Editor]) was installed on all workstations of the justice system.

2015 Austrian bailiffs were provided with the possibility to auction moveable items on the Internet auction platform of the justice system.

2016 Structured processing of titles and liens started to be possible. In the same year training in voice recognition software became a fixed part of the training schedule of trainee judges.

2016 - The Strategic Justiz 3.0 Initiative was introduced, with several parallel 2018 projects running to establish and optimise the bases of digital file management. Among other things, the prerequisites for a viable Austriawide scanning process and text recognition, a file document management and workflow system were created. For the purposes of a holistic view of the operations of the justice system this initiative aimed to find best possible IT support for all the different user groups up to a fully electronic handling of procedures in the light of current trends and opportunities.

2017 Condominium ownership rights were registered systematically and automatically as well.

At the same time the European order for payment procedure started ist operation for Austria and Germany by the (Austrian) Federal Computing Centre.

2017 The second, parallel system to the current system of EBR started to be available for EU-wide linking of companies. The Business Registers Interconnection System (BRIS) was established by the European Commission and provided the possibility to search for companies and corporations and to obtain commercial or business register excerpts and documents free of charge. In addition, the registers exchanged information about changes regarding parent companies.

2017 The IT support in criminal proceedings was set up.

2018 A total of 191 home typists (thereof 22 on parental leave and 26 retired staff members) were working as part of the Electronic paperwork Management system in Austria.

2018 It came to the digitisation and artificial intelligence. Since that time an AI service that has been 'trained' to meet the specific requirements of the justice system has been in use, which can be expanded step by step to other areas.

2019 The Electronic Enforcement Management (eVM) was set into force.

2019 Since 2019 online submission application for expert witnesses and interpreters should be mandatory. 
2019 - The E-Codex - ME-Codex shall be adopted. The project will be operated 2022 and maintained by an existing European agency, presumably from 2022, the duties are being fulfilled by the bridging project me-CODEX until November 2018 and presumably by the follow-up project me-CODEX II from 2 February.

In the following a short overview of the most important aspects of the Austrian e-justice system will be given with the focus on the electronic legal communication, the electronic registers, the electronic documents archive, the database of official publications, the Federal Law Information System, the Justiz-intranet, video conferencing and data security.

The Case Automation in the Justice Administration application supports all courts and public prosecutors' offices in keeping the registers. ${ }^{15}$ Some types of proceedings, for example the order for payment procedure are fully automated. Court decisions are issued automatically and dispatched via a centralized mailing line. ${ }^{16}$ Submissions and decisions are transmitted via the Electronic Legal Communication system. ${ }^{17}$ Court fees are collected as cashless payments. ${ }^{18}$

One of the most important achievements in Austrian e-justice is the electronic legal communication with the courts. It was introduced in $1990 .{ }^{19}$ The relevant legal source is the Regulation of the Federal Minister of Justice on the electronic legal communication ('ERV 2006'), ${ }^{20}$ which is based on Section 89b para. 2 Court Organisation Akt ('Gerichtsorganisationsgesetz - GOG'). ${ }^{21}$ The electronic legal communication has the same footing as submissions in hard copy. For submissions via electronic legal communication apply the same regulations as for submissions in hard copy (Section 89c para. 1 GOG). The electronic legal communication enables electronic transmission of submissions and an automatic receipt of the details in the case to the IT applications of the justice system. ${ }^{22}$ Submissions via electronic legal communication must be signed with an appropriate electronic signature. In accordance with Section 89c para. 5 GOG in particular lawyers, notaries, credit and financial institutions, insurance companies or social insurance agencies are obliged to participate in the electronic legal communication within the bounds of the technical possibilities. Since 2013 every citizen, who owns a citizen $\operatorname{card}^{23}$ is able to send

15 Brochure (n 97) 5.

16 Brochure (n 97) 5.

17 Brochure (n 97) 5.

18 Source Federal Ministry of Justice, e-Justice Austria, IT applications in the Austrian justice system, Information Brochure (n 97) 5.

19 Der Elektronische Rechtsverkehr (ERV) <https://www.justiz.gv.at/web2013/home/e-justice/ elektronischer-rechtsverkehr-erv 2c9484852308c2a60123708554d203e7.de.html> accessed 9 December 2019.

20 BGBl (2005) II (481).

21 Bundesrecht konsolidiert: Gesamte Rechtsvorschrift für Elektronischer Rechtsverkehr, Fassung vom 02.08.2018<https://www.ris.bka.gv.at/GeltendeFassung.wxe?Abfrage=Bundesnormen\& Gesetzesnummer=20004493> accessed 9 December 2019.

22 Brochure (n 97) 7.

23 Brochure (n 97) 15. 
electronic submissions to all courts and public prosecutors' offices via www.eingaben. justiz.gv.at by means of secured communication. ${ }^{24}$

In 1999 the 'justice system's data highway' was opened. It enables electronic service of process documents from the courts to the parties in the so-called 'return communication. ${ }^{25}$ Since 2009 courts and public prosecutors' offices are able to send judgments, transcripts and other documents as pdf attachments via electronic legal communication. For court rulings and other documents via electronic legal communication apply the same regulations as for court rulings in hard copy (Section 89c para. 3 GOG).

The importance of the electronic legal communication is shown by the key figures for 2016: ${ }^{26} 14,7$ million transactions, including 4,8 million submissions (this is more than $94 \%$ of all actions and approx. $76 \%$ of all petitions for enforcement) 7,6 million electronic submissions plus 2,3 million case number replies.

Court-appointed and certified expert witnesses and interpreters are able to submit expert opinions or translations, including attachments, in a secured electronic way to the offices of the justice system via the documents submission service. ${ }^{27}$

A further priority of the Austrian e-justice system is the register databases. As the first register database the Land Register database was set up at the Federal Computing Centre in the early 1980s. It has enabled automated keeping of the Land Register by the courts and automated keeping of the cadastre by the surveying offices. ${ }^{28}$ Since the middle of 1999 the Austrian Land Register can be inspected via the internet throughout the world. ${ }^{29}$ For external searches of the Land Register database so-called clearing offices were established. ${ }^{30}$

In 1991 the foundation for the central electronic Business Register was laid. The Business Register contains the data of all Austrian business entities that are subject to registration (main register). ${ }^{31}$ The documents which are relevant to registration are stored in the Electronic Archive of Documents of the justice system (Collection of Documents 'Urkundensammlung'). ${ }^{32}$

The electronic Business Register as well as the Land Register database have been integrated into the service landscape of the justice system. Applications may be filed electronically or as a hard copy. Public announcements of the Business Register Courts are made fully automatically in the Database of Official Publications ('Ediktsdatei'). ${ }^{33}$

24 Brochure (n 97) 7.

25 Brochure (n 97) 7.

26 Brochure (n 97) 7.

27 Brochure (n 97) 12

28 Brochure (n 97) 8.

29 See Information zum ERV <http://edikte.justiz.gv.at//edikte/km/kmhlp05.nsf/all/gbneu!Open Document $>$ accessed 9 December 2019.

30 Brochure (n 97) 8; for further information please see <http://www.justiz.gv.at> accessed 9 December 2019.

31 Das Firmenbuch <https://www.justiz.gv.at/web2013/html/default/8ab4a8a422985de30122a90fc2 ca620b.de.html> accessed 9 December 2019.

32 Brochure (n 97) 9.

33 Brochure (n 97) $9 \mathrm{f}$. 
Business Register documents are served via Electronic Legal Communication System, via the justice systems' delivery service or via a central dispatch office ('mailing line') by post. Since 2017 the Business Register has been linked with other European registers via BRIS (Business Registers Interconnection System). Focused on corporations the system features Europe-wide search functions and document queries as well as notifications of insolvencies, liquidations and mergers. ${ }^{34}$

By virtue of the migration of the Land Register and the Business Register to ITbased systems it became necessary to establish an electronic documents archive too. Nevertheless it took several years until a central archive of documents emerged. ${ }^{35}$ The electronic documents archive can be used for all types of applications, proceedings and procedures. There will be a possibility to archive documents (e.g. electronically signed contracts) from the court in a database in any application and in any type of proceedings, and to establish a link to the same. In this way a document once stored in the archive could be used in different legal proceedings. Since 2005 the collections of documents of all Business Register courts have been kept exclusively electronically. Since 2006 the same applies for the Land Register. ${ }^{36}$

Notices or other official documents get announced in the database of Official Publications ('Ediktsdatei'). ${ }^{37}$ The database of Official Publications is available to the general public without any registration or costs via internet. ${ }^{38}$ In this database all matters from the area of insolvency (in particular, opening of insolvency proceedings, compositions, debt regulations) ${ }^{39}$ are exclusively published and legally binding. ${ }^{40}$ Furthermore the following matters are published in this database: official publications about auctions of real property; announcements of the Business Register Courts; auction edicts regarding movable items; the option to search for property owners in criminal cases, declarations of death, court declarations of invalidity etc.

A significant facilitator in the procedure of taking evidence is the use of video conferencing. ${ }^{41}$ Since 2005 the procedural law requirements have been fulfilled for use of video conferencing equipment in examinations of witnesses and defendants in preliminary criminal proceedings, of witnesses at trials, and of witnesses, parties, interpreters and expert witnesses in civil proceedings (Section 277 Civil Procedure Order - ZPO). Video conferencing technology offers the judges a possibility to summon

\footnotetext{
$34 \quad$ Brochure (n 97) 10.

35 Brochure (n 97) 14.

36 Brochure (n 97) 14.
}

37 Der Ediktsdatei <https://www.help.gv.at/Portal.Node/hlpd/public/content/99/Seite.991589.html> accessed 9 December 2019; for a list of the legal basis of the Database of Official Publications see Ediktsdatei - Impressumsdaten <http://www.univie.ac.at/zib/pdf/Ediktsdatei_Impressumsdaten.pdf> accessed 9 December 2019.

38 Ediktsdatei <http://edikte.justiz.gv.at/edikte/edikthome.nsf> accessed 9 December 2019.

39 Section 14 Insolvency Introductory Act - IEG; Section 255 ff Insolvency Code - IO.

40 Brochure (n 97) 13; see also Henriette-Christine Duursma/Duursma-Kepplinger, 'Funktion und Wirkungen der österreichischen Insolvenzdatei' (2002) 19 ZInsO 913.

41 More about the success story of video conferencing in Austrian procedural law please see Die Justiz und die Videokonferenz - eine Erfol gsg eshchichte <https://www.justiz.gv.at/web2013/home/justiz/ aktuelles/aeltere-beitraege/2012/die-justiz-und-die-videokonferenz--eine-erfolgsgeschichte 2c948485 342383450134cd9be45e0304.de.html> accessed 9 December 2019. 
persons who must be examined by a different court by way of judicial assistance to the court equipped with a video conferencing system which is the closest to their home and to directly examine them via video conferencing. ${ }^{42}$. Video conferencing ultimately leads to a saving of time and costs for the courts, the parties and the persons being examined. Since 2011 all courts, public prosecutors' office and prisons have been equipped with video conferencing systems. In 2016 a total of around 3,700 video conferences were held Austria-wide, of which approximately $25 \%$ were with foreign courts. ${ }^{43}$

A very useful facility is the Federal Law Information System (RIS).$^{44}$ It was established in the course of Austrian e-Government. ${ }^{45}$ It is an online documentation of the Austrian legislation and jurisdiction. It is available to the general public without any registration or costs via Internet. The staff of the justice system can use this database tool at all workplaces. ${ }^{46}$ The new RIS, which is based on Internet technology, allows for an even more efficient search for desired information and, therefore, a faster decision-making process. Important parts of the RIS system, such as, e.g., the statutory provisions or the rulings of the Supreme Administrative Court ('Verwaltungsgerichtshof') or of the Supreme Constitutional Court ('Verfassungsgerichtshof') and those of the ordinary courts of law are available to the general public free of charge on the Internet. ${ }^{47}$

The intranet of the justice system is an internal information portal only for all staff of the department and an important work tool. ${ }^{48}$ It is based on the same concepts and technologies as the Internet. The intranet is a central access point to all internal and to selected external web applications and information for the staff of the justice system. ${ }^{49}$ Internal web applications such as the Integrated Prison Administration, Webmail, the Collection of Forms, the Collection of Ministerial Orders, international judicial assistance or maintenance of the Database of Official Publications may be retrieved quickly, easily and in a structured manner. External applications, including but not limited to the Federal Law Information System RIS, the Land Register, the Business Register or the Central Register of Residents, may be reached via these applications as well. $^{50}$

\subsection{Common Elements of E-justice in Ukraine and Austria}

What elements of e-justice are introduced in Ukraine? And which elements of e-justice are common in Ukraine and Austria? Elements of electronic justice ${ }^{51}$ are fixed in the

\footnotetext{
$42 \quad$ Brochure (n 97) 34.

43 Brochure (n 97) 34.

44 Das Rechtsinformationssystem des Bundes (RIS), <http://www.ris.bka.gv.at> accessed 9 December 2019.

45 E-Government in Österreich <https://www.digitales.oesterreich.gv.at/e-government-in-osterreich> accessed 9 December 2019.

46 Brochure, op.cit. Brochure (n 97) 25.

47 Brochure (n 97) 25.

48 Brochure (n 97) 29.

49 Brochure (n 97) 29.

50 Brochure (n 97) 29.

51 Note: in Ukraine there was a unification of processes, which, before 2017 had significant differences. The relevant articles of the procedural codes are identical in content.
} 
three Procedural Codes of Ukraine (Art. 14 of the Civil Procedural Code of Ukraine, Art. 6 of the Commercial Procedural Code of Ukraine and Art. 18 of the Code of Administrative Proceedings of Ukraine). ${ }^{52}$ In Austria this is fixed in various legal sources. Most important is the Regulation of the Federal Minister of Justice on the electronic legal communication ('ERV 2006'), ${ }^{53}$ which is based on Section 89b para. 2 Court Organisation Akt ('Gerichtsorganisationsgesetz - GOG'). ${ }^{54}$

These elements can be called differently in each legal system, but the content is almost identical. This situation is quite understandable, since the development of the provisions on e-justice in Ukraine took into account the experience of electronic justice in the United States and Europe. So, if to compare e-justice in Austria and Ukraine, then the following elements of e-justice are common: 1) submission of a statement of claim, applications, other documents to the court in electronic form; 2) payment of court fee; 4) exchange of documents between the courts, the court and the participants in the process; 5) sending of announcements, communications, decisions to the participants of the court process; 6) consideration of the case in electronic form; 7) holding a videoconference; 8) electronic evidence and so on.

Let's take a look at some of these elements. It is worthwhile to focus on three elements - submission of the statement of claim, applications, other documents to the court in electronic form, electronic evidence and consideration of the case in electronic form, because they are actually new if to compare provision of old and new Procedural Codes of Ukraine

\subsubsection{Submission of the Statement of Claim, Applications, Other Documents to the Court in Electronic Form.}

Until April 2017, the Provisional Rules for the Exchange of Electronic Documents between the Court and the Participants in the Court Process, ${ }^{55}$ where the procedure for the submission by the participants of the court proceedings to the court of documents in electronic form was established, as well as the electronic submission of such procedural documents to the participants in parallel with the documents in paper in accordance with the procedural law. At the same time, such electronic court communication was unilateral, since there was only the possibility of sending procedural documents to the court at the request of the participants in the process. Since July 2015, three pilot courts in Ukraine have been identified, in which such communication was electronically carried out bilaterally. In general, the results of this pilot project can be evaluated positively. Since there is a huge demand for such services, namely, that a person,

52 Civil Procedural Code of Ukraine<http://zakon2.rada.gov.ua/laws/show/1618-15> accessed 9 December 2019; Commercial Procedural Code of Ukraine <http://zakon3.rada.gov.ua/laws/ show/1798-12> accessed 9 December 2019; Code of Administrative Proceedings of Ukraine <http:// zakon3.rada.gov.ua/laws/show/2747-15> accessed 9 December 2019.

53 BGBl (3005) II ( 481).

54 Bundesrecht konsolidiert: Gesamte Rechtsvorschrift für Elektronischer Rechtsverkehr, Fassung vom 02.08.2018<https://www.ris.bka.gv.at/GeltendeFassung.wxe?Abfrage=Bundesnormen\& Gesetzesnummer=20004493> accessed 9 December 2019.

55 Temporal Regulation of court documents exchange between court and parties <https://ck.court.gov.ua/ tu24/gromadyanam/timreglament/> accessed 9 December 2019. 
without leaving home, had the opportunity to apply to the court for the protection of the violated right and get a judicial decision in the shortest possible time. ${ }^{56}$ But in any case, such communication could only take place after the opening of the proceedings. The only judicial system provides for the two-way exchange of documents in all courts of Ukraine, as well as the possibility of applying to the court in electronic form in fact with the requirement to open proceedings in order to protect rights or interests.

In Austria complaints have to be filed via electronic communication, if a party is represented by a lawyer. In this case all written submissions in civil procedural proceedings have to be lodged via electronic communication. Only not represented parties are not forced to use the electronic communication. But they can use it as far as they have a citizen card with electronic signature. For the return communication apply the same rules.

\subsubsection{Electronic Evidence}

Evidence lies at the heart of every civil procedure. ${ }^{57}$ Their introduction into the process is important in today's conditions when the contracts are concluded on the Internet. Electronic evidence is information in an electronic (digital) form that contains facts relevant to the case, including electronic documents (including text documents, graphic images, plans, photographs, video and audio recordings, etc.), web-sites (pages), text, multimedia and voice messages, metadata, databases and other data in electronic form. Such data may be stored, for example, on portable devices (memory cards, mobile phones, etc.), servers, back-up systems, and other places of data storage in electronic form (including the Internet).

It cannot be said that electronic evidence was not used in Ukrainian practice at all. However, there was no complete understanding of this legal institution. Therefore, often the courts did not take them as evidence at all in the case. Irregularity of electronic evidence in the Ukrainian national civil procedural law prevented their effective use. ${ }^{58}$ Electronic evidence is actually a 'novelty' in the processes..$^{59}$

In Austria documents can also be transmitted via electronic communication. This particular applies for civil procedural proceedings. In other proceedings, such as proceedings concerning the Land Register or the Business Register documents can also be transmitted in electronic way via registration in the Electronic Archive of Documents. It is not provided to send documents e.g. via email or USB-stick. Another question is, if video, mobile phones and other data carrier may be used as evidence. Austrian law provides this.

56 The results of pilot project of e-court were presented in Odessa, see $<$ http://rsu.gov.ua/ua/news/v-odesiprezentovano-rezultati-pilotnogo-/proektu-elektronnij-sud > accessed 9 December 2019.

57 See Cornelious H van Rhee, Alan Uzelac, 'Evidence in civil procedure: the fundamentals in light of the 21st century' <https://www.academia.edu/29595337/Evidence_in_Civil_Procedure_the_ fundamentals_in_light_of_21st_century > accessed 9 December 2019.

58 See AYu Kalamaiko, 'Electronni zasoby dokazuvannia v tsyvilnomu protsesi' ('Electronic means of proof in civil process') (PhD thesis, Yaroslav Mudryi National Law University 2016) < dspace.nlu.edu. ua/bitstream/123456789/10659/1/Kalamaiko_A_Yu_2016.pdf> accessed 10 December 2019.

See Viktoriia Melnychenko, 'Elektronni dokazy: "novynka” u protsesi' ('Electroni proof; a "novelty" in the process') (2017) 52 (602) Yurydychna Hazeta <http://yur-gazeta.com/publications/practice/ sudova-praktika/elektronni-dokazi-novinka-u-procesi.html> accessed 10 December 2019. 


\subsubsection{Consideration of the Case in Electronic Form}

This element of e-justice provided for by Ukrainian law, from our point of view, is both interesting and complicated. Since the procedural codes contain only one phrase: 'The court conducts consideration of the case on the materials of the court case in electronic form. The following articles do not contain any provisions on how this should be done. Perhaps the legislator plans that this will be done by the Regulation of the Single Judicial Information and Telecommunication System. But at the present time, the question arises whether a trial should be held in such a case, which process participants should be notified of? At the moment there is no answer. And on this occasion, neither theorists nor practitioners express their position.

In Austria it is not provided to conduct a case in electronic form in general. Only the electronic order for payment procedure ('ADV-Mahnverfahren') provides a decision of the court without an oral proceeding (Section $250 \mathrm{ff}$ Civil Procedure Order - ZPO) ${ }^{60}$ Apart from that a deviation from the principle of directness is only provided due to video conferencing.

The consolidation in the procedural codes of the relevant article on the Judicial System also did not mean its full-scale use since the entry into force of these codes. The legislator has foreseen a transitional period for this. According to the transitional provisions, the Uniform Judicial System 'starts functioning 90 days after the announcement by the State Judicial Administration of Ukraine and the web portal of the judiciary about the creation and maintenance of the functioning of the Single Judicial Information and Telecommunication System. When it happens in Ukraine we can not to say.

\section{POTENTIAL RISKS AND BENEFITS OF E-JUSTICE EXPERIENCE IN AUSTRIA AND UKRAINE}

\subsection{The Main Features of E-justice and Risks}

The Austrian e-justice demands a high standard on security and further qualitative requirements on IT solutions. ${ }^{61}$ For this purpose the federal ministry of justice has formulated an Austrian e-justice strategy. ${ }^{62}$ According to this an adequate performance and availability of the IT solutions and data has to be ensured. The authenticity, integrity and confidentiality of the stored or transmitted data have to be guaranteed. It must be ensured, that unauthorised third parties without permission cannot use or compromise the IT solutions. The IT security includes all endangered and worth protecting technical

60 See Hanz Dolinar, Marianne Roth, Henriette Duursma-Kepplinger, Zivilprozessrecht, 14 vol (Jan Sramek Verlag 2016) 328.

61 Federal Ministry of Justice, Österreichische e-Justiz Strategie (Austrian e-justice strategy), Version 3.3. (Stand: 12.06.2017) p. 24, 25 (in the following: Strategy) p. 24, 25 <https://www.justiz.gv.at/web2013/ home/e-justice 8ab4ac8322985dd501229ce3fb1900b4.de.html> accessed 10 December 2019.

62 Ibid. The currently valid 'e-Government Vision 2020' as well as the 'E-Government-Strategy' of the platform Digital Austria ('Plattform Digitales Österreich - PDÖ) <https://www.digitales.oesterreich. gv.at/e-government-strategie-des-bundes> accessed 10 December 2019, <https://www.digitales. oesterreich.gv.at/e-government-vision-2020> accessed 10 December 2019. 
equipment and facilities, e.g. hardware, software, networks, communication facilities, operating instructions and other software solution documentation. ${ }^{63}$ IT security demands administrative and technical measures to reduce the potential risk for the IT solutions. Protective measures comprise elaborating security designs for developing and operating the IT solutions and implementing the security standards set force within those designs, e.g. the use of access permissions. ${ }^{64}$ Measures of IT security should in particular detect and prevent unauthorised access to systems, applications and data. They should detect and avoid safety-critical software and configuration errors. ${ }^{65}$ Measures of IT security are subject to economic aspects. The level of protection depends on a risk assessment. Efficient security measures have to be established at all levels such as data, applications and infrastructure. ${ }^{66}$ This is ensured through a proactive and systematic approach of an IT security structure. The emphasis is on high system security at storage and transmission of data. The risks of use of new communication channels had to be reduced through appropriate measures.

The long-term storage of all proceedings' data increases the risk of loss of physical data, such as the paper files. ${ }^{67}$ In the course of the widespread use of mobile data carriers, e.g. smartphones, USB memory cards special attention should be given on securing digitally stored data. ${ }^{68}$

Since 2007 the electronic legal communication works on a web-based technology using open standards, such as, e.g., XML, WebServices or SOAP. ELC, which is secured by SSL and certificates. It can be accessed via several transmission points and inter alia provides for the possibility to send exhibits in the form of attachments together with the electronically submitted brief. ${ }^{69}$

When introducing the Judicial System in Ukraine it is necessary to take into account the potential risks and problems that may arise. It is clear that it takes some time to find out all the problems and make suggestions to fix them.

However, certain risks and problems are already available because Ukraine has some experience due to using of separate elements of electronic justice. And also it is necessary to take into accounts the experience of Austria in this point.

The first risk that can be called is the total or partial destruction of information contained in the Judicial System. In June 2017, a number of hack attacks were carried out on various Ukrainian structures, in particular, the State Fiscal Service of Ukraine. ${ }^{70}$ In this aspect, it is important to create the proper protection of information contained in the Judicial System, for example, by copying information

$63 \quad$ Strategy (n 144) 24, 25.

64 Strategy (n 144) 24, 25.

65 Strategy (n 144) 24, 25.

66 Strategy (n 144) 24, 25.

67 Strategy (n 144) 24, 25.

68 Strategy (n 144) 24, 25.

69 Strategy (n 144) 7.

70 See SFS suspends acceptance of documents because of virus Petya.A attack <https://tsn.ua/groshi/ dfs-prizupinila-priyom-elektronnih-dokumentiv-cherez-ataku-virusu-petya-a-952577.html > accessed 9 December 2019. 
to an additional server. They should not even be the potential disappearance of a large amount of information on court cases in particular in the context of guaranteeing basic human rights and freedoms. ${ }^{71}$

The second potential risk is the ability to get information about process participants to third parties (names, addresses, etc.), that is, that according to the legislation is personal data. As noted above in Austria, an entire strategy has been developed on this subject, which provides for high standards on security.

Are there other problems / risks of e-justice in Ukraine? Yes, exactly, for example, a problem as the lack of 'computer literacy'. ${ }^{72}$ Other authors also note among the problems: lack of funds and dissonance of information technology and procedural rules. $^{73}$ We think that each year, these problems will gradually diminish / disappear, because Austria at the beginning of establishment of e-justice had similar problems. Such similar problems are characteristic of almost all the states that introduced e-justice. ${ }^{74}$

Another important, in our opinion, problem is the availability of e-mail addresses for the possibility of using the Judicial System. As for legal entities, lawyers, notaries, experts, etc., the participants are required to register electronic addresses using the electronic digital signature in the Judicial System. As for ordinary citizens, such a duty does not exist. Therefore, the question arises how simple citizens can be in the situation when they became participants in the process? At present, this problem is solved in such a manner that individuals submit court applications, where they specify the electronic addresses at which it is possible to send information (notice of the court hearing, documents on the case). However, this information is used only for one specific case. Austria has similar approaches to the inclusion of individuals in the court portal. Individuals are voluntarily included in this portal. In our view, the problem may disappear when individuals will understand the necessity of the legal advice provided by lawyers which are already included in this system.

Speaking about the risks and problems, we consider it most important to pay attention to the advantages of the full implementation of the Judicial System in Ukraine and Austria.

In our opinion, the first and most important advantage is saving time and money. Most Ukrainian scientists and practitioners point to these advantages. Other advantages include speeding up of disputes, facilitating access of process participants to case materials; simplifying the work of all subjects of legal proceedings.

The Austrian e-justice system can be described as stable and secure. It is based on a very high technical standard. Technical failures or disruptions are very rare, indeed.

71 See Dubinskaya $v$ Russia, application No 4856/03 <http://hudoc.echr.coe.int/eng?i=001-76343> accessed 10 December 2019.

72 See NV Kushakova-Kostytska, 'Elektronne pravosuddia: ukrainski realii ta zarubizhnui dosvid' ('E-justice: Urrainian realities and foreign experience') (2013) 1 Yurydychnyi Chasopys Natsionalnoi Akademii Vnutrishnikh Sprav 103-109.

73 See Draft Law On the Main Grounds of Cyber Security in Ukraine <http://w1.c1.rada.gov.ua/pls/ zweb2/webproc4_2?id=\&pf3516=2126\%D0\%B0\&skl=9> accessed 10 December 2019.

74 João Rosa, Risk factors in e-justice information systems <https://www.sciencedirect.com/science/ article/pii/S0740624X13000385> accessed 10 December 2019. 
Damages due to hacker or other cyber-attacks on the Austrian E-justice System are as far as can be seen not reported. ${ }^{75}$

\subsection{What Makes the Procedure More Effective?}

The benefits of the Austrian e-justice system prevails the potential risks and problems so far. The most important risk factor is the field of data security and cyber-attacks. As said, the Austrian e-justice system operates at a very high technical level. Furthermore there is great effort to ensure data security. On this background the risks are tolerable in comparison to the benefits. The implementation of the e-justice system has led to a significant reduction of costs in the area of justice. This applies in particular to savings in publication costs, postage and personnel costs. Solely the database of Official Publications has led to a reduction in publication costs of $95 \% .{ }^{76}$ Once the final stage of electronic legal communication is reached, it will mean an estimated 133 staff members less. ${ }^{77}$ In 2016 savings on postage worth more than EUR 12 million were made due to electronic legal communication. ${ }^{78}$ Overall the implementation of e-justice system has the advantage for the Federal Republic of Austria of expenses saved.

The users of the e-justice system (staff of the courts, parties, attorneys, etc.) also benefit due to shorter length of proceedings, saving of time because of the (full) automation in various types of proceedings etc. Nonetheless, it cannot be overlooked that the initial acquisition costs for the necessary hard and software represent a not insignificant cost factor for external users (in particular attorneys and notaries). When introducing a liable e-justice system this factor should be considered. Appropriate long transitional phases can help to solve this problem.

\section{CONCLUSION}

Introduction of the Judicial System in Ukraine in the area of justice is an objective phenomenon and meets the requirements of time. However, for its full-fledged work, it is necessary to adopt the relevant Regulation, where all aspects (procedural, technical, etc.) related to its functioning will be settled in more detail and clearly correlated with the norms of the procedural codes. It is worth considering the security of this Judicial System in order to protect personal data and prevent the destruction of all given as such in general in the case of hacker attacks. In this field the technical experience of the Austrian e-justice and e-government systems could be helpful. Austrian Justice System is very broad. Some parts available in Austria are not yet available in Ukraine, such as Family and Youth Court Support Register. Other components, such as the Business Registry exist in Ukraine, but they are not part of a Judicial System.

\footnotetext{
$75 \quad$ For further information to cyber security in Austria see <http://archiv.bundeskanzleramt.at/DocView. axd?CobId=66026> accessed 11 December 2019.

76 Brochure (n 97) 7.

77 Brochure (n 97) 7.

78 Brochure (n 97) 7.
} 
When developing the Regulation on a Judicial System in Ukraine, it is necessary to take into account such aspects as providing information security, protecting personal data, expanding the elements of electronic justice which exist in Austria. When implementing an e-justice system in the Ukraine, the emphasis should be set on the electronic communication. To support this, the establishment of an electronic documents archive and a database of official publications would be very useful. At the second stage Business Registry, Land Register and other Registers should be automatically connected with the justice electronic communication system.

The introduction of e-justice is an important element of modernization of legal proceedings, promotes the rule of law and increases public trust to the state as a whole and in particular to the court system. The introduction of electronic justice in the Ukrainian justice will bring it closer to the common minimum standards of civil procedure that are being declared in the European space.

Lastly, the full implementation of e-justice in Austria lasted more than 30 years. In Ukraine, the introduction of e-justice has been going on for more than 10 years. We do not agree with the opinion of some scholars that fully electronic civil proceedings will be at the end in several decades. ${ }^{79}$ The development of IT technology is at an insidious pace. Therefore, we believe that the electronic justice system in Ukraine will function fully in the next ten years. This is confirmed by the experience of Austria.

79 See Yu Navrotska, O Ugrynovska, 'Tendentsii electronizatsii tsyvilnoho sudochynstva Ukrainy' ('Tendencies of digitalization of civil procedure in Ukraine') (2017) 8 Pravo Ukrainy 130. 